\title{
Comparison of Maternal Outcomes of Daily and Weekly Iron Tablet Supplementation in Pregnant Women in Coastal Region, Medan, Indonesia
}

Muhammad Rizki Yaznil*, Muara Panusunan Lubis, Sarma Nursani Lumbanraja, Melvin Nova Gunawanto Barus, Munauwarus Sarirah

Department of Obstetrics and Gynecology, Faculty of Medicine, Universitas Sumatera Utara, Medan, Indonesia

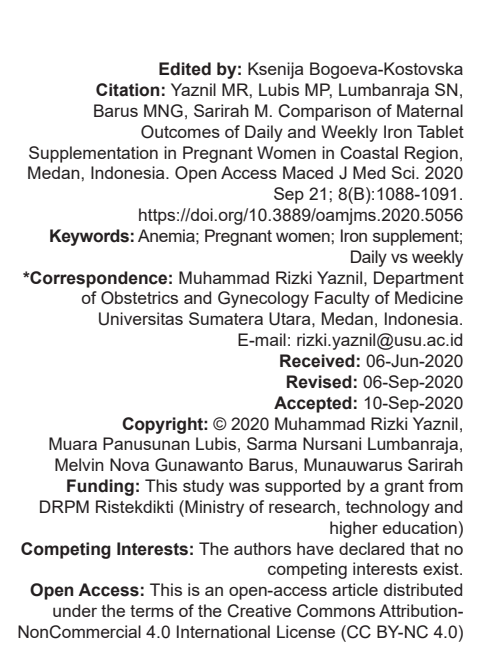

Abstract

BACKGROUND: Weekly consumption of iron supplementation is preferred to daily consumption of iron supplementation because of its minimal side effects and higher level of compliance.

AIM: This study is to compare the maternal outcomes in pregnant women with daily and weekly consumption of iron supplementation in coastal region.

METHODS: This prospective cohort study was conducted from July 2018 to January 2019 in Belawan Health Cente and Medan Deli Health Center. Sixty-two pregnant women who met inclusion and exclusion criteria were given iron supplement everyday (Group 1, $\mathrm{n}=29$ ) and twice a week (Group 2, $\mathrm{n}=33$ ). Hemoglobin levels, hematocrit, and ferritin serum are tested before starting the iron supplementation. All numerical data were analyzed using t-test.

RESULTS: There is no significant difference in mean hemoglobin and hematocrit before and after iron supplementation $p=0.222$ and $p=0.793$, respectively, however, decreasing level of ferritin serum from 41.21 to $26.29 \mathrm{ng} / \mathrm{ml}(p=0.001)$ is found. Hemoglobin, hematocrit, and ferritin serum means, before and after supplementation were not statistically different between daily and weekly group $(p=0.421, p=0.197, p=0.917)$

CONCLUSION: To prevent iron deficiency anemia in pregnant women, weekly or daily iron supplementation show similar effectiveness although continuous consumption of iron supplementation during breastfeeding period is needed to restore iron loss during pregnancy.

\section{Introduction}

Iron deficiency anemia has been a common nutritional problem in pregnant women; it is due to increasing iron requirements in pregnant women, especially in the second and third trimesters [1]. Iron deficiency anemia increases the risk of postpartum hemorrhage that causes maternal mortality in Indonesia.

Therefore, the Indonesian government made a policy of giving daily 90 iron tablets for 3 months during antenatal care [2]. Meta-analysis of Haider et al. showed that iron tablet supplementation increases the maternal hemoglobin concentration of $0.46 \mathrm{~g} / \mathrm{dl}$ compared to controls and effectively reduces the risk of iron deficiency anemia [3].

However, it is important to consider that the absorption of intestine to iron is limited; therefore, the supplementation is not only useless but also increasing side effects [4]. Recent studies found that daily iron supplements increase lipid peroxidation [5] and reduce zinc absorption [6], [7]. Frazer et al. showed that periodic iron supplementation enhances mucosal healing and increase iron absorption [8].

Several studies have been conducted to find alternative regimens for iron administration in pregnant women that will minimize side effects and affect compliance [9], [10], [11], [12]. Recent studies showed that weekly iron supplementation has the similar effectiveness as daily iron supplementation in non-anemic pregnant women [12] and reduce the risk of high hemoglobin concentration in the middle and end of pregnancy [13]. Mukhopadhyay et al. stated that weekly iron supplementation was an effective choice for prophylaxis in non-anemic pregnant women, but is not beneficial in anemic women [14]. Majority of people living in coastal areas have low socio-economic levels [15]. This study aims to compare the maternal outcomes between pregnant women with daily and weekly iron supplementation in Indonesian coastal region. 


\section{Materials and Methods}

\section{Samples and data collection}

This prospective cohort study was conducted from July 2018 to January 2019 involving 201 pregnant women who came to Belawan Health Center and Medan Deli Health Center. The inclusion criteria were non anemic pregnant women with gestational age of 13-28 weeks, pregnant women who approved informed consent and could provide contact person for follow-up. The exclusion criteria were pregnant women with malignancies and multiple pregnancies.

Blood count and ferritin serum level were examined at the first visit. Samples were divided into two groups. The first group was given daily iron supplements while the second group was given iron supplements twice a week on Tuesday and Friday for 3 months. One iron tablet contains $180 \mathrm{mg}$ of ferrous fumarate and $400 \mathrm{~g}$ of folic acid. The tablets were manufactured by Phapros $^{R x}$. After 3 months, the patients were contacted by mobile phone or through their midwife to come to the Health Center for routine blood evaluation and ferritin serum levels. The blood samples were examined by Prodia Laboratory using Sysmex XN 1000.

\section{Statistical analysis}

Data were analyzed using SPSS software. Age, gestational age, history of pregnancy, and hematological value of the daily and weekly supplementation groups were analyzed using independent-t test. Blood count and ferritin serum levels before and after supplementation were analyzed using paired-t test. Significant value was set at $p<0.05$.

\section{Results}

The area of research in our study is about $21.82 \mathrm{~km}^{2}$ with a height about $3 \mathrm{~m}$ above sea levels. The northern part of the area is directly adjacent to the Malacca Strait. The mean population density is 4499 people $/ \mathrm{km}^{2}$ [16]. Average net income per month of the population in the research area was less than 2 million rupiah which is the average income in Indonesia [17].

From 201 pregnant women included in this study, only 62 subjects could be admitted for the evaluation of iron supplementation for 3 months based on selection criteria. The daily iron supplementation groups were 29 pregnant women $(46.77 \%)$ and the weekly supplementation groups was 33 pregnant women $(53.23 \%)$. Subject characteristics are shown in Table 1. The mean age of subjects was $27.87 \pm 5.96$ years with the youngest age was 19 years and the oldest age was 40 years. The mean gestational age was $21.02 \pm 4.90$ weeks with the youngest gestational age was 12 weeks and the oldest was 31 weeks. There were no significant differences in age and gestational age between the daily iron supplementation groups and the weekly groups $(p>0.05)$.

Table 1: Characteristics of the subjects

\begin{tabular}{llll}
\hline Characteristics & Daily $(\mathrm{n}=29)$ & Weekly $(\mathrm{n}=33)$ & p value \\
\hline Age (years) & $28.55 \pm 6.06$ & $27.27 \pm 5.90$ & 0.404 \\
Gestational age (weeks) & $20.46 \pm 4.54$ & $21.50 \pm 5.22$ & 0.419 \\
History of pregnancy & & & \\
$\quad$ Primigravida & $7(24.14)$ & $9(27.27)$ & \\
$\quad$ Secundigravida & $12(41.38)$ & $10(30.30)$ & \\
$\quad$ Multigravida & $9(31.03)$ & $13(39.39)$ & \\
$\quad$ Grand emultigravida & $1(3.45)$ & $1(3.03)$ & \\
Initial hematological value & & & \\
$\quad$ Hemoglobin $(\mathrm{g} / \mathrm{dl})$ & $11.60 \pm 0.95$ & $11.33 \pm 0.96$ & 0.272 \\
$\quad$ Hematocrit $(\%)$ & $34.20 \pm 2.41$ & $33.76 \pm 2.02$ & 0.572 \\
$\quad$ Platelet $\left(\mathrm{x} 10^{3} / \mathrm{ll}\right)$ & $309.52 \pm 50.89$ & $297.82 \pm 60.33$ & 0.416 \\
Leukocytes $\left(\mathrm{x} 10^{3} / \mu \mathrm{l}\right)$ & $10.83 \pm 2.53$ & $10.24 \pm 2.29$ & 0.341 \\
$\quad$ ESR $(\mathrm{mm} / \mathrm{hour})$ & $60.97 \pm 29.05$ & $56.00 \pm 19.29$ & 0.438 \\
$\quad$ Serum ferritin $(\mathrm{ng} / \mathrm{ml})$ & $43.32 \pm 32.72$ & $39.35 \pm 35.17$ & 0.648 \\
\hline
\end{tabular}

Regarding the history of pregnancy, 16 subjects $(25.81 \%)$ were primigravida, 22 subjects $(35.48 \%)$ were secundigravida, 22 subjects $(35.48 \%)$ were multigravida, and two subjects $(3.23 \%)$ were grand emultigravida. Before iron supplementation, there were no significant differences in the mean hemoglobin levels, hematocrit, and serum ferritin between the daily and weekly iron supplementation groups $(p>0.05)$. Of all subjects enrolled in this study, there was no significant difference between the mean hemoglobin levels before iron supplementation $(11.46 \pm 0.96 \mathrm{~g} / \mathrm{dl})$ and after three months of supplementation (11.30 \pm $0.85 \mathrm{~g} / \mathrm{dl})(\mathrm{p}=0.222)$.

The mean hematocrit before iron supplementation was $34.00 \pm 2.61 \%$ and the mean hematocrit after iron supplementation was $34.11 \pm$ $2.56 \%(p=0.793)$. The mean ferritin serum levels after iron supplementation was lower $(26.29 \pm 21.84 \mathrm{ng} / \mathrm{ml})$ compared to those before iron supplementation (41.21 $\pm 33.82 \mathrm{ng} / \mathrm{ml})(\mathrm{p}=0.001)$.

In the daily group, there were no significant differences in the mean hemoglobin levels before and after iron supplementation $(11.60 \mathrm{~g} / \mathrm{dl}$ vs. $11.33 \mathrm{~g} / \mathrm{dl}, \mathrm{p}=0.141)$, as well as the weekly group (11.33 g/dl vs. $11.27 \mathrm{~g} / \mathrm{dl}, \mathrm{p}=0.744$ ) (Table 2). However, the mean ferritin serum levels after iron supplementation was significantly lower compared to those before supplementation $(27.90 \mathrm{ng} / \mathrm{mlvs} .43 .32 \mathrm{ng} / \mathrm{ml}, \mathrm{p}=0.013)$. As the daily group, the mean of ferritin serum before supplementation in weekly group was lower compared to those after supplementation $(24.87 \mathrm{ng} / \mathrm{ml}$ vs. 39.35 $\mathrm{ng} / \mathrm{ml})$, but not statistically different $(p=0.070)$. The differences of the mean hemoglobin levels and the difference of the mean ferritin serum levels between daily and weekly group were not statistically different $(0.27$ vs. $0.06 \mathrm{~g} / \mathrm{dl}, \mathrm{p}=0.421)$ for hemoglobin concentration and 15.42 vs. $14.47 \mathrm{ng} / \mathrm{ml}, \mathrm{p}=0.917$ ) for ferritin serum (Table 2). 
Table 2: Hematological value of the initial and the final of supplementation

\begin{tabular}{|c|c|c|c|c|c|c|c|}
\hline \multirow[t]{2}{*}{ Hematological value } & \multicolumn{3}{|l|}{ Daily (Mean \pm SD) } & \multicolumn{3}{|l|}{ Weekly (Mean \pm SD) } & \multirow[t]{2}{*}{$p$ value } \\
\hline & Before supplementation & After supplementation & Difference & Before supplementation & After supplementation & Difference & \\
\hline Hemoglobin (g/dl) & $11.60 \pm 0.95$ & $11.33 \pm 0.74$ & $0.27 \pm 0.96$ & $11.33 \pm 0.96$ & $11.27 \pm 0.95$ & $0.06 \pm 1.06$ & 0.421 \\
\hline Hematocrit (\%) & $34.20 \pm 2.41$ & $33.76 \pm 2.02$ & $0.44 \pm 2.4$ & $33.76 \pm 2.02$ & $34.41 \pm 2.94$ & $-0.59 \pm 3.62$ & 0.197 \\
\hline Platelet $\left(\times 10^{3} / \mu \mathrm{l}\right)$ & $309.52 \pm 50.89$ & $293.76 \pm 55.86$ & $15.76 \pm 44.07$ & $297.82 \pm 60.33$ & $316.33 \pm 69.49$ & $-18.52 \pm 51.10$ & 0.007 \\
\hline Leukocyte $\left(\times 10^{3} / \mu \mathrm{l}\right)$ & $10.83 \pm 2.53$ & $10.29 \pm 1.87$ & $0.54 \pm 1.92$ & $10.24 \pm 2.29$ & $10.02 \pm 2.26$ & $0.22 \pm 2.31$ & 0.551 \\
\hline ESR (mm/hour) & $60.97 \pm 29.05$ & $49.69 \pm 22.07$ & $11.28 \pm 22.18$ & $56.00 \pm 19.29$ & $49.45 \pm 14.91$ & $6.55 \pm 19.82$ & 0.379 \\
\hline Serum ferritin $(\mathrm{ng} / \mathrm{ml})$ & $43.32 \pm 32.72$ & $27.90 \pm 24.49$ & $15.42 \pm 31.53$ & $39.35 \pm 35.17$ & $24.87 \pm 19.50$ & $14.47 \pm 38.57$ & 0.917 \\
\hline
\end{tabular}

\section{Discussion}

Iron supplementation is highly recommended to prevent iron deficiency anemia in pregnant women. These were due to increasing iron requirement for the growth of the placenta and fetus [18]. This study aims to compare the anemia level of pregnant women with daily and weekly iron supplementation who attended Belawan Health Center and Medan Deli Health Center. Our study showed decreasing level in hemoglobin before and after iron supplementation in the daily group as well as the weekly group, but it was not statistically significant. The change of hemoglobin concentration was not statistically different between daily and weekly groups ( $p=0.421$ ) A recent study found that in non-anemic pregnant women, the weekly iron supplementation was an effective alternative to the daily supplementation for preventing anemia and iron deficiency [19]. The weekly iron supplementation benefits pregnant women in serum iron and total iron binding capacity (TIBC) [20]; therefore, iron deficiency anemia in pregnant women can be prevented.

The difference of ferritin serum before and after iron supplementation between daily and weekly group was not statistically different ( $p=0.917$ ). This result was similar with the study by Goonewardene and Senadheera [12], [19]. Several studies showed changes of ferritin serum level after iron supplementation in daily and weekly group [14], [20], [21], [22]. Sipra et al. found that ferritin serum levels increased in both groups. Zamani et al. and Mukhopadhyay et al. study showed increasing level of ferritin serum in the daily group and decreasing level of ferritin serum level in weekly group.

Our study shows decreasing level in the mean of ferritin serum level before and after supplementation in both groups ( $p=0.001)$; however, the level did not reach the minimum standard level of ferritin serum (12 ng/ml) [23]. Decreasing level of ferritin serum was physiological due to the hemodilution process and high demands of the iron, especially in mid-trimester of pregnancy [24].

However, a recent study found that pregnant women in all trimesters had low level of ferritin serum [25]. The limitation of our study is small number of subjects that is being analyzed due to the geographical factor of area where most of them live in fishing villages that have limited access to the clinic. The other obstacles are the loss of communication for continuous evaluation and lack of family supports.

\section{Conclusion}

In our study, we found that weekly iron supplementation was as effective as daily iron supplementation in non-anemic pregnant women. Therefore, the regimen can be recommended to improve the compliance (medical adherence) of the patients, especially in coastal region. The iron supplementation should be continued during breastfeeding period to restore iron loss during pregnancy.

\section{Acknowledgment}

The authors are deeply thankful to Head of Belawan and Medan Deli Health Center, midwifes of Belawan and Medan Deli Health Center, Adriani Sakina, and Risfi Dwiandra Sartika Nasution for helping to collect samples and data in the field.

\section{References}

1. Cunningham F, Gant N, Leveno K. William's Obstetrics. $21^{\text {st }}$ ed Newyork: McGraw-Hill Medical Publishing Div.; 2005.

2. Permenkes RI. Standar Tablet Tambah Darah Bagi Wanita Usia Subur dan Ibu Hamil. Jakarta: Permenkes RI; 2014.

3. Haider B, Olofin I, Wang M, Spiegelman D, Ezzati M, Fawzi W Anaemia, prenatal iron use, and risk of adverse pregnancy outcomes: Systematic review and meta-analysis. BMJ. 2013;346:f3443. https://doi.org/10.1136/bmj.f3443 PMid:23794316

4. Almatsier S. Prinsip Dasar IImu Gizi. Jakarta: Gramedia Pustaka Umum; 2008.

5. Bhatla N, Kaul N, Kriplani A, Agarwal N, Saxena R, Gupta S. Comparison of effect of daily versus weekly iron supplementation during pregnancy on lipid peroxidation. J Obstet Gynaecol Res. 2009;35(3):438-45. https://doi. org/10.1111/j.1447-0756.2008.00972.x

PMid:19527380

6. Lachili B, Hininger I, Faure H, Arnaud J, Richard M, FavierA, et al. Increased lipid peroxidation in pregnant women after iron and Vitamin C supplementation. Biol Trace Elem Res. 2001;83(2):103-10. https://doi.org/10.1385/bter:83:2:103 PMid:11762527

7. Olivares M, Pizarro F, Ruz M, de Romaña D. Acute inhibition of iron bioavailability by zinc: Studies in humans. Biometals. 
2012;25(4):657-64. https://doi.org/10.1007/s10534-012-9524-z PMid:22297381

8. Frazer D, Anderson G. The orchestration of body iron intake: How and where do enterocytes receive their cues? Blood Cells Mol Dis. 2003;30(3):288-97. https://doi.org/10.1016/ s1079-9796(03)00039-1

PMid: 12737947

9. Hyder S, Persson L, Chowdhury A, Ekström E. Do side-effects reduce compliance to iron supplementation? A study of daily and weekly-dose regimens in pregnancy. J Health Popul Nutr. 2002;20(2):175-9.

PMid: 12186198

10. Beard J. Effectiveness and strategies of iron supplementation during pregnancy. Am J Clin Nutr. 2000;71:1288S-94S. https:// doi.org/10.1093/ajcn/71.5.1288s PMid:10799404

11. Galloway R, McGuire J. Daily versus weekly: How many iron pills do pregnant women need? Nutr Rev. 1996;54(10):318-23. https://doi.org/10.1111/j.1753-4887.1996.tb03795.x PMid:9063022

12. Bouzari Z, Basirat Z, Zeinal Z, Cherati S, Ardebil M, Mohammadnetaj $M$, et al. Daily versus intermittent iron supplementation in pregnant women. BMC Res Notes. 2011;4(1):444. https://doi.org/10.1186/1756-0500-4-444 PMid:22026956

13. Peña-Rosas J, de-Regil L, Garcia-Casal M, Dowswell T. Daily oral iron supplementation during pregnancy. Cochrane Database Syst Rev. 2015;7:CD004736. https://doi.org/10.1002/14651858. cd004736.pub5

PMid:26198451

14. Mukhopadhyay A, Bhatla N, Kriplani A, Pandey R, Saxena R. Daily versus intermittent iron supplementation in pregnant women: Hematological and pregnancy outcome. J Obstet Gynaecol Res. 2004;30(6):409-17. https://doi. org/10.1111/j.1447-0756.2004.00223.x PMid:15566454

15. Ginting B, Arif MN, Subhilhar S, Hamdani RH. Analysis of weaknesses of coastal community economy empowerment program (PEMP) and national program of community empowerment of independent marine and fisheries
(PNPM-MKP) on traditional fishermen in Indonesia. Jr Sci Res. 2018;4:41-53.

16. BPS. Kecamatan Medan Belawan dalam Angka. Medan: BPS 2017.

17. BPS. Income Statistics August. Jakarta: BPS; 2018.

18. Chandra S, Tripathi A, Mishra S, Amzarul M, Vaish A. Physiological changes in hematological parameters during pregnancy. Indian J Hematol Blood Transfus. 2012;28(3):144-6. https://doi.org/10.1007/s12288-012-0175-6 PMid:23997449

19. Goonewardene I, Senadheera D. Randomized control trial comparing effectiveness of weekly versus daily antenatal oral iron supplementation in preventing anemia during pregnancy. J Obstet Gynaecol Res. 2018;44(3):417-24. https://doi. org/10.1111/jog.13546 PMid:29271022

20. Sipra B, Shanti S, Kimmi A, Goel J. Effect of weekly iron supplementation on iron indices in pregnant women. Int J Med Res Health Sci. 2015;4(4):857-60. https://doi. org/10.5958/2319-5886.2015.00170.8

21. Gonewardene M, Liyanage C, Fernando R. Intermittent oral iron supplementation during pregnancy. Ceylon Med J. 2001;46(4):132-5. https://doi.org/10.4038/cmj.v46i4.6440

22. Zamani A, Farajzadegan Z, Ghahiri A, Khademloo M. Effectiveness of twice weekly iron supplementation compared with daily regimen in reducing anemia and iron deficiency during pregnancy: A randomized trial in Iran. J Res Med Sci. 2008;13:230-9.

23. Daru J, Allotey J, Peña-Rosas J, Khan K. Serum ferritin thresholds for the diagnosis of iron deficiency in pregnancy: A systematic review. Transfus Med. 2017;27:167-74. https://doi. org/10.1111/tme.12408

PMid:28425182

24. Hallberg L. Iron requirement, iron balance and iron deficiency in menstruating and pregnant women. In: Hallberg L, Asp NG, editors. Iron Nutrition in Health and Disease. London: George Libbey; 1996. p. 165-82.

25. Kumar S, Dubey N, Khare R. Study of serum transferrin and serum ferritin during pregnancy and their correlation with pregnancy outcome. Int J Med Sci Public Health. 2017;6:11822. https://doi.org/10.5455/ijmsph.2017.04072016570 